\title{
Involvement of tyrosine kinase and cAMP-dependent kinase cross-talk in the regulation of human sperm motility
}

\author{
M. Bajpai* and G. F. Doncel ${ }^{\dagger}$ \\ Contraceptive Research and Development (CONRAD) Program, Department of Obstetrics \\ and Gynecology, Eastern Virginia Medical School, Norfolk, VA 23507, USA
}

Tyrosine phosphorylation and its upregulation by cAMP have been associated with capacitation and motility changes of spermatozoa. In the present study, washed spermatozoa were incubated for $6 \mathrm{~h}$ in protein-supplemented complete medium with or without kinase inhibitors to verify whether upstream activation of protein kinase $A$ is indispensable for tyrosine phosphorylation and motility changes to occur in capacitating human spermatozoa. H89, a specific protein kinase $A$ inhibitor, significantly inhibited the activity of sperm protein kinase A. However, this inhibition did not alter capacitation-related tyrosine kinase activation. Tyrosine phosphorylated proteins, motion parameters and the incidence of phosphotyrosineimmunoreactive spermatozoa were decreased only slightly. Conversely, genistein, a tyrosine kinase inhibitor which inhibited sperm tyrosine kinase but not protein kinase A, significantly reduced all the parameters studied. Spermatozoa incubated with cAMP and pentoxifylline showed a rapid enhancement of tyrosine phosphorylation and some of the sperm motion parameters, particularly hyperactivation. Inclusion of $\mathbf{H 8 9}$ reduced cAMP stimulation of tyrosine kinase, and tyrosine phosphorylation and motion parameters were reduced almost to basal values. Treatment with genistein reduced tyrosine kinase activity, especially in the soluble fraction of sperm extracts. A decrease in tyrosine phosphorylation of soluble proteins, $105,81,55$ and $48 \mathrm{kDa}$, correlated with a significant reduction in sperm motion parameters. Hyperactivation was reduced by tenfold. Tyrosine phosphorylated proteins in the insoluble fraction and the incidence of tyrosine phosphorylated-positive spermatozoa were not reduced markedly. Upstream protein kinase A activation may be a facilitatory rather than an indispensable step in the capacitation-induced tyrosine phosphorylation mediating motility changes in human spermatozoa. Triton- $x 100$ soluble tyrosine phosphorylated proteins, more than their insoluble counterparts, appear to be involved in the modulation of human sperm motion characteristics.

\section{Introduction}

Capacitation is a time-dependent process that involves numerous morphological and structural changes in the spermatozoon (Yanagimachi, 1994). These changes occur at two levels: the sperm plasma membrane and the intracellular compartment. At the intracellular level, there are changes in ions, increased glycolytic activity and oxygen consumption, and increased activity of the adenylcyclase-cAMP-protein kinase A system. However, the sperm plasma membrane appears to be the initial target of capacitation, as it loses its coating materials (decapacitation factors), experiences a net deglycosylation, changes its phospholipid composition, loses cholesterol, increasing membrane fluidity and protein mobility, displays new surface receptors, and ac-

*Present address: Oregon Health Science University, Department of Endocrinology, Portland, OR 97201, USA

${ }^{\dagger}$ Correspondence address: CONRAD Program - Department of OB/GYN, Eastern Virginia Medical School, 601 Colley Ave, Norfolk, VA 23507, USA

Email: DoncelGF@evms.edu tivates transductional mechanisms that facilitate the two most visible changes in capacitated spermatozoa: their ability to acrosome react and to develop hyperactivated motility (Yanagimachi, 1994).

Tyrosine phosphorylation in spermatozoa has been associated with capacitation (for a review, see Visconti and Kopf, 1998). However, its trigger, regulatory processes, kinases, phosphatases and target proteins, as well as the ultimate effectors of capacitation-related changes, have not been completely elucidated. Furthermore, there are some indications that these factors may not be the same in different species (Visconti et al., 1995a, 1999; Carrera et al., 1996; Luconi et al., 1996; Vijayaraghavan et al., 1997a). Owing to the head and tail compartmentalization of the sperm cell and the essentially different functions that these compartments display, zona pellucida binding and penetration, acrosome reaction at the head and motility at the tail, the above factors might not even be the same in these two compartments of the spermatozoon.

Visconti et al. (1995b) demonstrated that cAMP can upregulate tyrosine phosphorylation at the same time that 
it facilitates the acquisition of sperm fertilizing ability. When administered exogenously, in some species, it can bypass the main requisites for sperm capacitation such as the presence of bicarbonate and cholesterol efflux (Visconti et al., 1995b; Galantino-Homer et al., 1997; Osheroff et al., 1999; Visconti et al., 1999). Although there appears to be a clear relationship between protein kinase $\mathrm{A}$ and tyrosine phosphorylation in human spermatozoa, whether upstream activation of protein kinase $\mathrm{A}$ is an indispensable condition for tyrosine kinase activation and tyrosine phosphorylation remains to be clearly established. Alternatively, activation of protein kinase A might play a facilitatory action on tyrosine kinase and tyrosine phosphorylation, contributing to its regulation together with other factors (for example, intracellular $\mathrm{Ca}^{2+}$ concentration, $\mathrm{pH}$, redox status, ATP) that are known to change during capacitation. This facilitatory action on tyrosine phosphorylation would occur in addition to the role of protein kinase $\mathrm{A}$ as a modulator of capacitation events, effected by serinetheronine protein phosphorylation.

The present study has focused on the regulation of human sperm motion characteristics by protein tyrosine phosphorylation. In addition, the study has assessed cross-talk between cAMP-dependent kinase and tyrosine kinase. The findings were verified from different approaches by evaluating tyrosine kinase and protein kinase A activity, tyrosine phosphorylation of sperm proteins in both soluble and whole-cell extracts, and the incidence of tail tyrosine phosphorylation in capacitating spermatozoa incubated with and without CAMP and kinase inhibitors.

\section{Materials and Methods}

\section{Reagents}

Kinase inhibitors, H89 (N-[2-(p-bromocinnamyamino)ethyl]-5-isoquinolinesulphonamide $\cdot 2 \mathrm{HCl}), \mathrm{H} 8$ (N-[2-(methylamino)ethy-5-isoquinoline-sulphonamide . $2 \mathrm{HCl})$, staurosporin and genistein (4,5,7-trihydroxyisoflavone) were obtained from Bio-Mol (Plymouth Meeting, PA). Ham's F10 medium was obtained from Gibco Biotechnology (Rockville, MD). Phosphotyrosine antibody (4G10) was purchased from Upstate Biotechnology (Lake Placid, NY), and fluorescein isothiocyanate anti-mouse IgG from Capple (Aurora, $\mathrm{OH}$ ) and anti-quenching buffer from Molecular Probes (Eugene, OR). N,2-O-dibutyryladenosine 3',5'-cyclic monophosphate (dbcAMP), 3,7-dimethyl-1-(5-oxohexyl)xanthine (pentoxifylline), human serum albumin (HSA), BSA and all other reagents were obtained from Sigma Chemical Company (St Louis, MO).

\section{Preparation of sperm sample}

Human semen samples were obtained from consenting donors by masturbation after $3-5$ days of abstinence under a protocol approved by the Institutional Review Board. Only samples with normal semen analysis $\left(>50 \times 10^{6}\right.$ motile spermatozoa $\mathrm{ml}^{-1}$, motility $\left.>50 \%\right)$ were used in the experiments. After liquefaction for $30 \mathrm{~min}$, the seminal plasma was removed by washing in Ham's $\mathrm{F} 10+0.35 \%$ HSA. Washed spermatozoa $\left(10 \times 10^{6}\right.$ cells $\left.\mathrm{ml}^{-1}\right)$ were studied immediately $(t=0)$ or after $6 \mathrm{~h}$ of incubation at $37^{\circ} \mathrm{C}$ in $5 \% \mathrm{CO}_{2}(t=6)$ with or without kinase inhibitors $\mathrm{H} 89\left(25 \mu \mathrm{mol} \mathrm{I}^{-1}\right)$, genistein $\left(400 \mu \mathrm{mol} \mathrm{I}^{-1}\right), \quad \mathrm{H} 8 \quad\left(500 \mu \mathrm{mol} \mathrm{I}^{-1}\right)$ and staurosporin $\left(1 \mu \mathrm{mol} \mathrm{I}^{-1}\right)$. The broad-spectrum kinase inhibitor, staurosporin, was used as a positive control for the assays. The negative controls consisted of medium with no inhibitors and up to $1 \%(\mathrm{v} / \mathrm{v})$ dimethyl sulphoxide, similar to the final concentration of dimethyl sulphoxide in the experimental tubes. The concentrations of the inhibitors used in all the experiments were selected from those that did not show any sperm cytotoxic effects in membrane integrity and mitochondrial function assays (see below). Aliquots of different experimental variants were evaluated for protein kinase $\mathrm{A}$ and tyrosine kinase activity, protein tyrosine phosphorylation, incidence of phosphotyrosine-immunoreactive spermatozoa and sperm motion parameters.

In a second set of experiments aimed at enhancing the protein kinase A-mediated upregulation of tyrosine phosphorylation, swim-up spermatozoa were incubated with $1 \mathrm{mmol}$ dibutyryl cAMP $\mathrm{I}^{-1}$ and $1 \mathrm{mmol}$ pentoxifylline $\mathrm{I}^{-1}$ with or without tyrosine kinase (genistein, $\left.400 \mu \mathrm{mol} \mathrm{I}^{-1}\right)$ or protein kinase $\mathrm{A}\left(\mathrm{H} 89,25 \mu \mathrm{mol} \mathrm{I} \mathrm{I}^{-1}\right)$ inhibitors for $90 \mathrm{~min}$ at $37^{\circ} \mathrm{C}$ in $5 \% \mathrm{CO}_{2}$. Again, aliquots of spermatozoa were characterized for their motility, motion characteristics, kinase activity and tyrosine phosphorylation.

\section{Assessment of sperm viability}

Dose-response experiments were used to select the concentrations of the inhibitors that did not significantly compromise sperm viability. Viability was checked by two procedures: the hypo-osmotic swelling test (HOST) (Jeyendran et al., 1984) and the mitochondrial function (MTT (3-(4,5-dimethylthiazol-2-yl)-5-(3-carboxymethoxphenyl)-2-(4-sulphophenyl)-2-H-tetrazolium) test (Levitz and Diamond, 1985). The HOST evaluates sperm plasma membrane integrity, whereas the MTT test is based on mitochondrial function. For the HOST, spermatozoa incubated with or without inhibitors were incubated further with hypo-osmotic medium $(75 \mathrm{mmol}$ fructose $\mathrm{I}^{-1}$ and $25 \mathrm{mmol}$ sodium citrate $\mathrm{I}^{-1}$ ) at $37^{\circ} \mathrm{C}$ and $5 \% \mathrm{CO}_{2}$ for $30 \mathrm{~min}$ and spermatozoa with coiled tails were counted as viable.

Another aliquot of spermatozoa was incubated with the MTT dye solution for $4 \mathrm{~h}$. In live spermatozoa the dye was converted into a coloured formazan product, the absorbance of which was read at $570 \mathrm{~nm}$. The concentration of inhibitors that did not display cytotoxic 
effects on spermatozoa during a $6 \mathrm{~h}$ incubation were used for subsequent experiments. Sperm viability was also examined after each experiment to minimize the effect of sample variability.

\section{Sperm motion parameters}

Motility and motion parameters of spermatozoa were assessed in a computer-assisted motion analyser (Hamilton Thorn v.10.8) using a $20 \mu \mathrm{m}$ deep chamber at $37^{\circ} \mathrm{C}$. Settings were as follows: frames, 30; frame rate, $60 \mathrm{~Hz}$; minimum contrast, 85; minimum cell size, 2 pixels; and minimum static contrast, 30 . The following parameters were used to define hyperactivation: curvilinear velocity $(\mathrm{VCL})>100 \mu \mathrm{m} \mathrm{s}^{-1}$, linearity of a curvilinear path (LIN) $<65 \%$, amplitude of lateral head displacement (ALH) > $7.5 \mu \mathrm{m}$ (Burkman, 1991).

The studied motion parameters can be defined as follows: VCL is the time-average velocity of a sperm head along its actual curvilinear path as perceived in two dimensions under the microscope; straight-line velocity (VSL) is the time-average velocity of a sperm head along the straight line between its first detected position and its last; average path velocity (VAP) is the time-average velocity of a sperm head along its average path; ALH is the magnitude of lateral displacement of a sperm head about its average path; and LIN is reported as a ratio VSL: VCL; straightness (STR) is the linearity of the average path (VSL/VAP); and beat-cross frequency (BCF) is the average rate at which the curvilinear path of a spermatozoon crosses its average path (World Health Organization, 1999).

\section{Indirect immunofluorescence}

Indirect immunofluorescence has been used to detect the incidence of tyrosine phosphorylated spermatozoa at different time points during a capacitating incubation. Spermatozoa $\left(10 \times 10^{6} \mathrm{ml}^{-1}\right)$ taken from the different experimental variants were washed in PBS $+0.1 \%$ BSA and $10 \mu \mathrm{l}$ of the samples were spotted on to eight-well slides. The slides were allowed to dry before proceeding. Spermatozoa were fixed and permeabilized in methanol for $30 \mathrm{~min}$ and then washed twice in PBS. Slides were incubated with phosphotyrosine antibody (4G10) for $1 \mathrm{~h}$, washed twice with PBS and incubated with antimouse IgG-fluorescence isothiocyanate for $30 \mathrm{~min}$ at room temperature $\left(25^{\circ} \mathrm{C}\right)$. After two washes in PBS, the slides were mounted in anti-quenching buffer (Slowfade light Antifade kit, Molecular Probes, Eugene, OR) and examined under a Nikon E800 epifluorescence microscope connected to a digital imaging system (Spot II, v.3.0 software, Sterling Heights, MI). Not fewer than 200 cells were counted.

\section{Solubilization of spermatozoa}

Spermatozoa from all experimental variants were washed twice with PBS and centrifuged at $400 \mathrm{~g}$ for
10 min. Spermatozoa $\left(10 \times 10^{6}\right.$ cells $\left.\mathrm{ml}^{-1}\right)$ were solubilized in $10 \mu \mathrm{l}$ SDS solubilization buffer $(0.0187 \mathrm{~mol}$ Tris- $\mathrm{HCl} \mathrm{I})^{-1}, \mathrm{pH}$ 6.8, containing $2 \%(\mathrm{w} / \mathrm{v})$ SDS, $10 \%(\mathrm{v} / \mathrm{v})$ glycerol, $1 \mathrm{mmol}$ vanadate $\mathrm{I}^{-1}$ and $1 \mathrm{mmol}$ phenylmethylsulphonyl fluoride (PMSF)) for $30 \mathrm{~min}$ at $25^{\circ} \mathrm{C}$. The sperm extract was then mixed with $10 \mu \mathrm{l}$ SDS-PAGE buffer $(0.0625 \mathrm{~mol}$ Tris-HCl I-1, $\mathrm{pH}$ 6.8, $2 \%$ SDS, $10 \%$ glycerol and $2 \%(\mathrm{v} / \mathrm{v}) 2$-mercaptoethanol) and heated at $100^{\circ} \mathrm{C}$ for $5 \mathrm{~min}$. Samples were loaded on to $7.5 \%(\mathrm{w} / \mathrm{v})$ polyacrylamide gels and subjected to electrophoresis. An equivalent of $1 \times 10^{6}$ spermatozoa was applied to each lane. Aliquots of spermatozoa were treated with Triton buffer $\left(50 \mathrm{mmol}\right.$ Tris- $\mathrm{HCl} \mathrm{I} \mathrm{I}^{-1}$ $(\mathrm{pH} 7.5), 10 \mathrm{mmol}$ benzamide $\mathrm{I}^{-1}, 5 \mathrm{mmol}$ EDTA $\mathrm{I}^{-1}$, $10 \mathrm{mmol}_{\text {EGTA I }}^{-1}, 1 \mathrm{mmol}$ vanadate $\mathrm{I}^{-1}, 1 \mathrm{mmol}$ PMSF $\mathrm{I}^{-1}$ and $0.05 \%$ Triton-X100) and centrifuged at $15800 \mathrm{~g}$ for 20 min to study soluble proteins. The supernatant was taken as the solublized fraction and was used for protein kinase A assay and to study tyrosine phosphorylation of soluble proteins by western blot analysis.

\section{Western blot analysis}

Samples were run on SDS-PAGE at a constant voltage of $125 \mathrm{~V}$. Proteins were transferred on to Immobilon $\mathrm{P}$ (Millipore, Bedford, MA) at a constant voltage (100 V) for $2 \mathrm{~h}$ and blocked with superblocker (Pierce, Rockford, IL) overnight at room temperature. Immobilon sheets were incubated with a 1:10000 dilution of monoclonal phosphotyrosine antibody (4G10) for $2 \mathrm{~h}$ in TBST $\left(0.02 \mathrm{~mol}\right.$ Tris- $\mathrm{HCl} \mathrm{I}^{-1}, 0.15 \mathrm{~mol} \mathrm{NaCl} \mathrm{I}{ }^{-1}, 0.05 \%(\mathrm{v} / \mathrm{v})$ Tween-20, pH 7.6) containing 5\% BSA. After washing twice with TBST, Immobilon sheets were incubated with anti-mouse secondary antibody (IgG-horseradish peroxidase), washed and then developed with AmplifiedOpti4CN kit from Bio-Rad (Hercules, CA). Images were taken with Spot II Digital Imaging System and molecular weights were calculated using Kodak Imaging System (v. 2.1) (New Haven, CT).

\section{Kinase activity}

Washed or swim-up spermatozoa $\left(10 \times 10^{6} \mathrm{ml}^{-1}\right)$ were solubilized in $100 \mu \mathrm{l}$ homogenizing buffer (20.0 mmol Hepes $\mathrm{I}^{-1}$, pH 7.4, 2.0 mmol EDTA I ${ }^{-1}, 1.0$ mmol dithiothreitol $\mathrm{I}^{-1}, 0.1 \mathrm{mmol}$ PMSG $\mathrm{I}^{-1}, 0.1 \mathrm{mmol}$ vanadate $\mathrm{I}^{-1}, 1.0 \mathrm{mmol} \mathrm{MgCl}_{2} \mathrm{I}^{-1}, 100.0 \mathrm{mmol} \mathrm{NaCl} \mathrm{I}^{-1}$ and $0.05 \%$ Triton-X100) for $15 \mathrm{~min}$ at $4{ }^{\circ} \mathrm{C}$. A Triton-X100 soluble fraction was obtained by sonicating spermatozoa $\left(10 \times 10^{6} \mathrm{ml}^{-1}\right)$ in homogenizing buffer and centrifuging at $15800 \mathrm{~g}$ for $30 \mathrm{~min}$ at $4^{\circ} \mathrm{C}$. The supernantant was used as the Triton-soluble fraction of sperm extracts. Kinase activity was determined in whole-cell and Tritonsoluble extracts at room temperature.

ELISA-based tyrosine kinase and protein kinase A kits were purchased from Cal-Biochem (San Diego, CA). Standard curves were run along with test samples in 


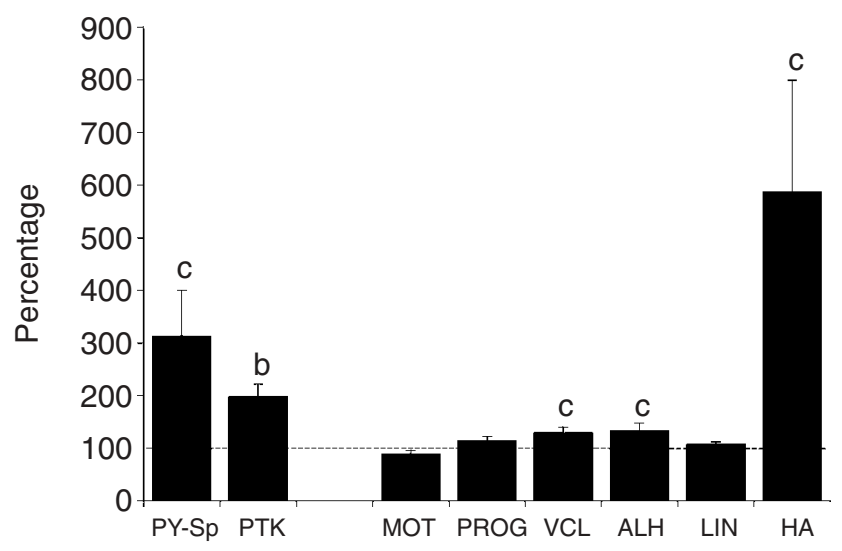

Fig. 1. Changes in protein tyrosine kinase (PTK) activity, incidence of phosphotyrosine-immunoreactive spermatozoa and motion parameters after a $6 \mathrm{~h}$ capacitating incubation in Ham's $\mathrm{F} 10+0.35 \%$ human serum albumin at $37^{\circ} \mathrm{C}$ in $5 \% \mathrm{CO}_{2}$. Data have been normalized against baseline preincubation values (equal to $100 \%$, indicated by dashed line). Superscripts indicate significance of data compared with baseline value $(100 \%)$ by Wilcoxon's signed-rank test (b: $P<0.001$; c: $P<0.05)$. ALH: amplitude of lateral head displacement, HA: hyperactivation, LIN: linearity, MOT: motility, PROG: progressive velocity, PYSp: phosphotyrosine-immunoreactive sperm tails, VCL: curvilinear velocity $(n=24)$.

each experiment and their activity expressed as $U \mathrm{mg}^{-1}$ protein. The protein content was determined using the Bio-Rad kit (Hercules, CA).

One Unit of protein kinase A activity is defined as the amount of enzyme required to catalyse the transfer of 1 pmol phosphate into the substrate (RFARKGSLRQKNV) in $1 \mathrm{~min}$ at $30^{\circ} \mathrm{C}$. One Unit of tyrosine kinase activity is defined as the amount of enzyme required to catalyse the transfer of 1 pmol phosphate to the peptide substrate
(EAIYAAPFAKKK) present at $100 \mu \mathrm{mol} \mathrm{I}^{-1}$ in $1 \mathrm{~min}$ at $30^{\circ} \mathrm{C}$ in $25 \mu$ reaction mixture.

\section{Statistical analysis}

The Wilcoxon's signed-rank test was used to analyse control normalized data. Mean percentages were compared with a hypothetical control mean of $100 \%$ (the control was spermatozoa incubated without inhibitor). In the cAMP plus pentoxifylline experiments, data were analysed using Welch's test or paired $t$ test depending on dispersion. All statistical analyses were performed with Prism software (Graphpad, San Diego, CA).

\section{Results}

Tyrosine phosphorylation and motility changes during a capacitating incubation

As previously reported, there was a significant increase in tyrosine kinase activity in human spermatozoa incubated for $6 \mathrm{~h}$ under capacitating conditions (Fig. 1). In addition, in parallel, there was an increase in the number and intensity of tyrosine phosphorylated sperm proteins and in the incidence of phosphotyrosine-immunoreactive spermatozoa at the end of such capacitating incubation (Figs 1, 2). The percentage of phosphotyrosine-immunoreactive spermatozoa increased from $13 \%$ at $t=0$ to $33 \%$ at $t=6$. Although sperm motility and progressive motility remained unchanged, some of the motion characteristics, such as VCL, ALH and the percentage of hyperactivated (HA) spermatozoa, increased in magnitude (Fig. 1).
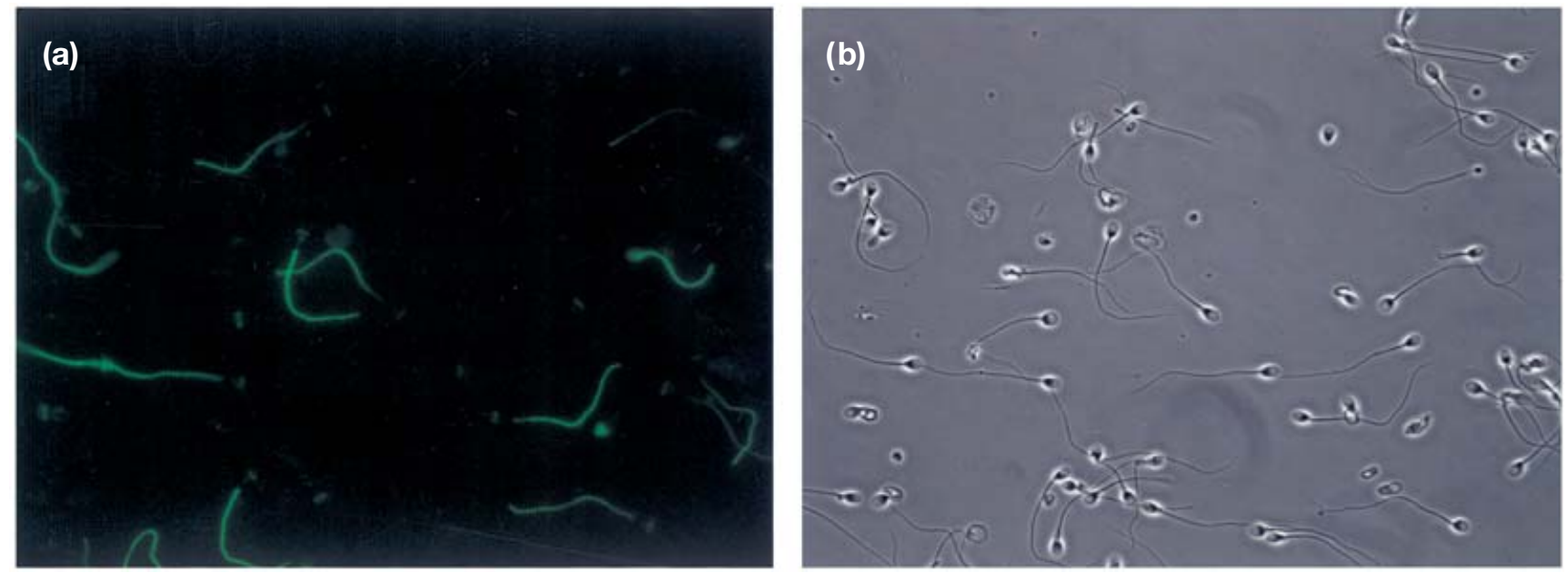

Fig. 2. Matching pair of photomicrographs. Immunolocalization of tyrosine phosphorylated proteins in human spermatozoa at the end of a capacitating incubation. Spermatozoa were fixed and permeabilized with methanol and immunolabelled with a phosphotyrosine antibody (4G10) and fluorescein isothiocyanate-conjugated anti-mouse IgG. (a) Fluorescent and (b) phase contrast photomicrographs. Scale bar represents $10 \mu \mathrm{m}$. 


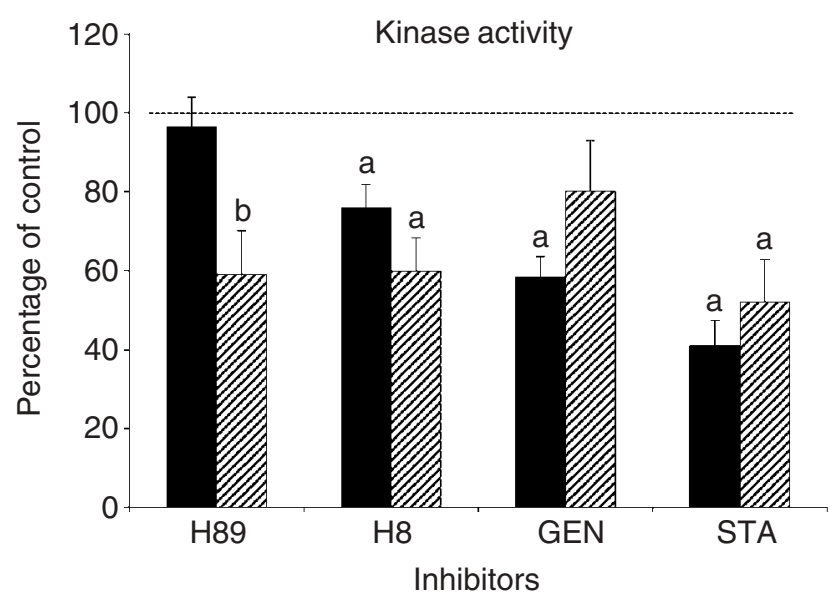

Fig. 3. Effect of protein tyrosine kinase (PTK, $\mathbf{\square})$ and protein kinase A (PKA, 㽠) inhibitors (H89, H8, genistein (GEN), staurosporin (STA)) on PTK and PKA activity in whole sperm extracts measured by a colorimetric immunoreaction (ELISA) detecting tyrosineand serine-phosphorylated target peptides. Data are expressed as mean \pm SE $(n=24$ for PTK; $n=10$ for PKA) and represent the percentage of control (control is PTK or PKA activity of spermatozoa after $6 \mathrm{~h}$ of incubation at $37^{\circ} \mathrm{C}$ in $5 \% \mathrm{CO}_{2}$ without the inhibitors; dashed line). Wilcoxon's signed-rank test was used to analyse data (versus control $=100 \%$ ). Superscripts indicate significance according to the Wilcoxon's test (a: $P<0.0001 ; b: P<0.001$ ).

Role of tyrosine kinase and protein kinase $A$ in regulation of motility of human spermatozoa

The involvement of protein kinase $A$ in the capacitation-related regulation of motility parameters and tyrosine phosphorylation was investigated by incubating washed spermatozoa with $25 \mu \mathrm{mol} H 89 \mathrm{I}^{-1}$, $500 \mu \mathrm{mol} \mathrm{H} 8 \mathrm{I}^{-1}, 400 \mu \mathrm{mol}$ genistein $\mathrm{I}^{-1}$ or $1 \mu \mathrm{mol}$ staurosporin $\mathrm{I}^{-1}$ in Ham's $\mathrm{F} 10+0.35 \% \mathrm{HSA}$ at $37^{\circ} \mathrm{C}$ in $5 \% \mathrm{CO}_{2}$ for $6 \mathrm{~h}$. The concentrations of the inhibitors used in these experiments were not toxic to human spermatozoa, as assessed by membrane integrity (HOST) and mitochondrial function (MTT) assays.

H89, a specific inhibitor of protein kinase A, significantly inhibited the activity of sperm protein kinase A (Fig. 3). However, this inhibition did not affect total tyrosine kinase activity, and only diminished the incidence of phosphotyrosine-immunoreactive spermatozoa by $20 \%$ (Fig. 4). Motion parameters were slightly decreased and hyperactivation was not affected (Table 1). Genistein, a tyrosine kinase inhibitor, did not alter protein kinase A activity (Fig. 3). However, as expected, it did inhibit sperm tyrosine kinase activity, decreasing the incidence of phosphotyrosinepositive spermatozoa and the magnitude of motion parameters, including hyperactivation (Fig. 4, Table 1). H8, a PKA inhibitor of wider spectrum, inhibited both sperm protein kinase $A$ and tyrosine kinase, decreasing the incidence of tyrosine phosphorylatedimmunoreactive spermatozoa (Figs 3,4). Motility and

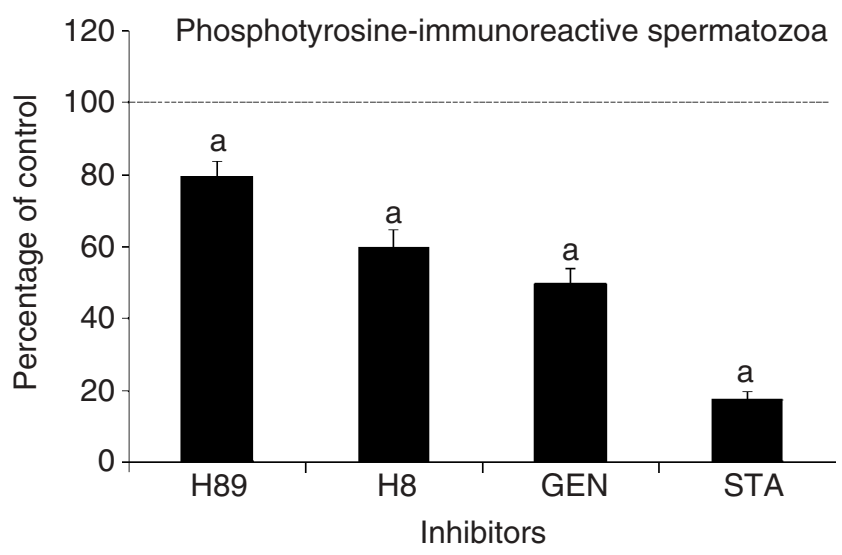

Fig. 4. Effect of protein tyrosine kinase and protein kinase $A$ inhibitors (H89, H8, genistein (GEN), staurosporin (STA)) on the incidence of phosphotyrosine-immunoreactive sperm tails after a $6 \mathrm{~h}$ incubation in Ham's F10 and human serum albumin at $37^{\circ} \mathrm{C}$ in $5 \% \mathrm{CO}_{2}$. Spermatozoa were fixed and permeabilized with methanol and labelled with phosphotyrosine monoclonal antibody (4G10) and fluorescein isothiocyanate-conjugated anti-mouse IgG. Data (mean $\pm S E, n=24$ ) are expressed as a percentage of control (after $6 \mathrm{~h}$ of incubation at $37^{\circ} \mathrm{C}$ in $5 \% \mathrm{CO}_{2}$ without inhibitors; dashed line). Wilcoxon's signed-rank test was used to analyse the normalized data (versus control $=100 \%$ ). Superscripts indicate significance obtained with the Wilcoxon's test (a: $P<0.0001)$.

progressive motility were decreased, whereas velocity was affected differentially according to the parameters considered (Table 1). The VAP and the VSL were reduced, whereas VCL was not affected. With increased ALH and decreased LIN, the percentage of hyperactivation spermatozoa was augmented. Similar changes, albeit more pronounced, were observed when staurosporin, which also inhibited protein kinase $\mathrm{A}$ and tyrosine kinase, was included in the medium.

Western blot analysis of whole sperm extracts revealed a slight decrease in the phosphotyrosineimmunoreactive bands of spermatozoa treated with H89 (Fig. 5). However, the decrease was more pronounced when spermatozoa were treated with H8. Genistein and staurosporin, as reported previously, significantly inhibited phosphotyrosine-immunoreactive bands. Two bands of approximately 162 and $83 \mathrm{kDa}$ were reduced in $\mathrm{H} 89$-treated spermatozoa and absent in $\mathrm{H} 8$-, genisteinand staurosporin-treated cells. In a similar way to staurosporin, although in most cases to a lesser extent, $\mathrm{H} 8$ significantly reduced all bands that were seen in the western blots of Triton-X100 solubilized spermatozoa. Conversely, treatment with H89 induced only a minor decrease in the intensity of the bands (Fig. 6).

cAMP-dependent enhancement of tyrosinephosphorylated proteins and motion parameters

In an attempt to characterize further the possible interaction between protein kinase $\mathrm{A}$ and tyrosine kinase 
Table 1. Effect of kinase inhibitors on changes in sperm motility that occur during a $6 \mathrm{~h}$ capacitating incubation

\begin{tabular}{|c|c|c|c|c|c|c|c|c|c|c|c|}
\hline Inhibitors & 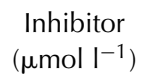 & $\begin{array}{l}\text { Percentage } \\
\text { motile }(\%)\end{array}$ & $\begin{array}{l}\text { Progressive } \\
\text { motility (\%) }\end{array}$ & VAP (\%) & VSL (\%) & VCL (\%) & $\mathrm{ALH}(\%)$ & BCF $(\%)$ & STR $(\%)$ & LIN (\%) & HA $(\%)$ \\
\hline H89 & 25 & $86.3 \pm 3.5^{\mathrm{a}}$ & $75.7 \pm 4.8^{\mathrm{a}}$ & $87.4 \pm 2.3^{\mathrm{a}}$ & $84.4 \pm 2.6^{a}$ & $92.1 \pm 3.2^{\mathrm{c}}$ & $96.6 \pm 2.9$ & $94.9 \pm 3.5$ & $94.3 \pm 1.7^{b}$ & $92.5 \pm 2.8$ & $106.9 \pm 13.2$ \\
\hline H8 & 500 & $69.6 \pm 5.0^{\mathrm{a}}$ & $45.2 \pm 4.7^{\mathrm{a}}$ & $74.5 \pm 4.0^{\mathrm{a}}$ & $68.5 \pm 3.4^{\mathrm{a}}$ & $92.1 \pm 4.1$ & $113.2 \pm 4.2^{b}$ & $92.1 \pm 3.7^{c}$ & $87.2 \pm 1.2^{\mathrm{a}}$ & $75.2 \pm 2.3^{\mathrm{a}}$ & $160.2 \pm 29.1$ \\
\hline GEN & 400 & $63.6 \pm 4.9^{\mathrm{a}}$ & $55.4 \pm 4.9^{a}$ & $67.2 \pm 2.5^{\mathrm{a}}$ & $63.9 \pm 2.9^{a}$ & $73.9 \pm 3.0^{\mathrm{a}}$ & $78.4 \pm 4.8^{a}$ & $93.5 \pm 4.1$ & $94.8 \pm 1.5^{b}$ & $88.8 \pm 3.3^{\mathrm{a}}$ & $38.9 \pm 9.9^{a}$ \\
\hline STA & 1 & $46.5 \pm 5.4^{\mathrm{a}}$ & $24.1 \pm 3.6^{\mathrm{a}}$ & $85.6 \pm 3.8^{b}$ & $65.0 \pm 3.1^{\mathrm{a}}$ & $105.6 \pm 4.5$ & $110.0 \pm 8.8$ & $103.8 \pm 6.7$ & $79.8 \pm 2.9^{\mathrm{a}}$ & $65.0 \pm 3.1^{\mathrm{a}}$ & $286.9 \pm 66.1$ \\
\hline
\end{tabular}

Washed spermatozoa were incubated with or without protein kinase A (H8, H89), protein tyrosine kinase (genistein, GEN) and wide spectrum kinase (staurosporin, STA) inhibitors in Ham's F10 and human serum albumin at $37^{\circ} \mathrm{C}$ for $6 \mathrm{~h}$. Motility and motion parameters were analysed using a Hamilton Thorne motion analyser ( $v 10.8$ ).

Values expressed as means \pm SEM $(n=24)$ represent percentages of control (6 h of incubation without inhibitors).

Superscripts indicate significant differences when compared with control (no inhibitors) by the Wilcoxon signed-rank test (a: $P<0.0001 ; b: P<0.005 ; \mathrm{c}: P<0.05$ ).

ALH: amplitude of lateral head displacement; BCF: beat-cross frequency; HA: hyperactivated; LIN: curvilinear path; STR: straightness; VAP: average path velocity; VCL: curvilinear velocity; VSL: straight line velocity.

Table 2. Effect of protein kinase A and protein tyrosine kinase inhibitors on cAMP and pentoxifylline (PTX)-stimulated sperm motion parameters

\begin{tabular}{|c|c|c|c|c|c|c|c|c|c|c|}
\hline & Motility & $\begin{array}{c}\text { Progressive } \\
\text { motility }\end{array}$ & VAP $(\%)$ & VSL (\%) & VCL $(\%)$ & $\mathrm{ALH}(\%)$ & BCF $(\%)$ & STR (\%) & LIN (\%) & $\mathrm{HA}(\%)$ \\
\hline cAMP/PTX & $90.7 \pm 3.7^{c}$ & $82.7 \pm 5.8^{b}$ & $113.8 \pm 3.7^{\mathrm{a}}$ & $108.9 \pm 4.9$ & $129.6 \pm 3.9^{a}$ & $136.9 \pm 4.3^{\mathrm{a}}$ & $99.7 \pm 3.7$ & $95.5 \pm 1.5^{b}$ & $87.0 \pm 3.5^{b}$ & $508.5 \pm 86.4^{\mathrm{a}}$ \\
\hline H89 + cAMP/PTX & $70.0 \pm 3.7^{a}$ & $63.2 \pm 4.6^{\mathrm{C}}$ & $93.5 \pm 2.6^{\mathrm{a}}$ & $91.2 \pm 2.9^{b}$ & $104.6 \pm 2.6^{\mathrm{a}}$ & $118.9 \pm 3.8^{\mathrm{a}}$ & $102.1 \pm 3.7$ & $96.0 \pm 0.9$ & $89.8 \pm 2.8$ & $241.5 \pm 26.6^{c}$ \\
\hline GEN + CAMP/PTX & $52.1 \pm 4.1^{\mathrm{a}}$ & $31.4 \pm 3.4^{\mathrm{a}}$ & $63.6 \pm 1.7^{\mathrm{a}}$ & $58.1 \pm 2.2^{\mathrm{a}}$ & $79.8 \pm 2.5^{\mathrm{a}}$ & $94.9 \pm 5.2^{\mathrm{a}}$ & $95.3 \pm 3.9$ & $88.3 \pm 1.1^{\mathrm{a}}$ & $75.2 \pm 2.2^{\mathrm{c}}$ & $56.7 \pm 9.4^{\mathrm{a}}$ \\
\hline
\end{tabular}

Swim-up spermatozoa were incubated with or without kinase inhibitors $\left(25 \mu \mathrm{mol} \mathrm{H} 89 \mathrm{I}^{-1}\right.$ or $400 \mu \mathrm{mol}$ genistein $\left.(\mathrm{GEN}) \mathrm{I}^{-1}\right)$ for $30 \mathrm{~min}$ and subsequently stimulated with cAMP and PTX ( $1 \mathrm{mmol} \mathrm{I} \mathrm{I}^{-1}$ each) for $1 \mathrm{~h}$. Motility and motion parameters were analysed with a Hamilton-Thorne motion analyser ( $v$ 10.8) and normalized against control (medium alone, no cAMP and PTX).

CAMP and PTX data were compared with control (100\%) with the Wilcoxon's signed-rank test.

The two variants containing kinase inhibitors were compared with cAMP/PTX using Welch's $t$ test.

Superscripts indicate significance (a: $P<0.0001 ;$ b: $P<0.001 ; \mathrm{c}: P<0.05$ ).

ALH: amplitude of lateral head displacement; BCF: beat-cross frequency; HA: hyperactivated; LIN: curvilinear path; STR: straightness; VAP: average path velocity; VCL: curvilinear velocity; VSL: straight line velocity. 


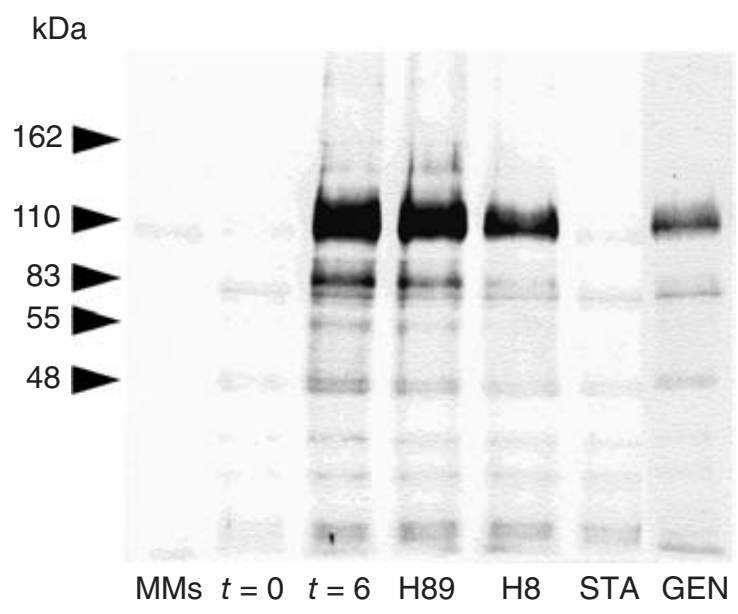

Fig. 5. Effect of protein tyrosine kinase and protein kinase $A$ inhibitors on sperm protein tyrosine phosphorylation at baseline $(t=0)$ and at $6 \mathrm{~h}$ of incubation $(t=6)$ in Ham's F10 and human serum albumin at $37^{\circ} \mathrm{C}$ in $5 \% \mathrm{CO}_{2}$. Proteins were extracted from washed spermatozoa in SDS-buffer, loaded on to a $7.5 \%(\mathrm{w} / \mathrm{v})$ polyacrylamide gel $\left(1 \times 10^{6} \mathrm{I}^{-1}\right.$ cells per lane), separated by electrophoresis, transferred to Immobilon $\mathrm{P}$ sheets and immunolabelled with phosphotyrosine antibody (4G10). Lanes were loaded with proteins extracted from untreated control spermatozoa ( $t=0$ and $t=6$ ) or spermatozoa incubated with the inhibitors (H89, H8, genistein (GEN), staurosporin (STA)) for $6 \mathrm{~h}$. The lane with genistein was run on a different gel using the same sperm sample. Images were taken with a SPOT II digital camera. Molecular masses of bands were determined using Kodak digital imaging system ( $v 2.1)(n=12)$. Arrowheads indicate the approximate molecular mass of the main visible protein bands. MMs: molecular markers.

in human spermatozoa, swim-up spermatozoa were incubated in Ham's $\mathrm{F} 10+0.35 \% \mathrm{HSA}$ at $37^{\circ} \mathrm{C}$ in $5 \%$ $\mathrm{CO}_{2}$ for $90 \mathrm{~min}$, under protein kinase A stimulation via a combination of $1 \mathrm{mmol}$ dibutyryl cAMP ${ }^{-1}$ and $1 \mathrm{mmol}$ pentoxifylline $\mathrm{I}^{-1}$, a phosphodiesterase inhibitor.

Although barely modifying total motility or progressive motility, cAMP plus pentoxifylline significantly increased VCL, ALH and especially, hyperactivation (Table 2, Fig. 7). Furthermore, cAMP plus pentoxifylline induced a parallel increase in protein kinase A activity in the soluble fraction of sperm extracts. Tyrosine kinase activity was increased too, particularly in the whole extract (Fig. 8). The incidence of tyrosine phosphorylatedpositive spermatozoa was augmented too (Fig. 9). When spermatozoa were incubated with cAMP plus pentoxifylline, almost all the bands in the western blots of whole sperm extracts were increased in intensity (Fig. 10). However, the soluble fraction showed a more selective pattern. Only bands with molecular masses of about 105, 81, 55 and $48 \mathrm{kDa}$ were consistently augmented (Fig. 11).

Inclusion of $\mathrm{H} 89$, an inhibitor of the catalytic subunit of protein kinase $A$, returned soluble protein kinase A activity to basal values (that is, without cAMP plus

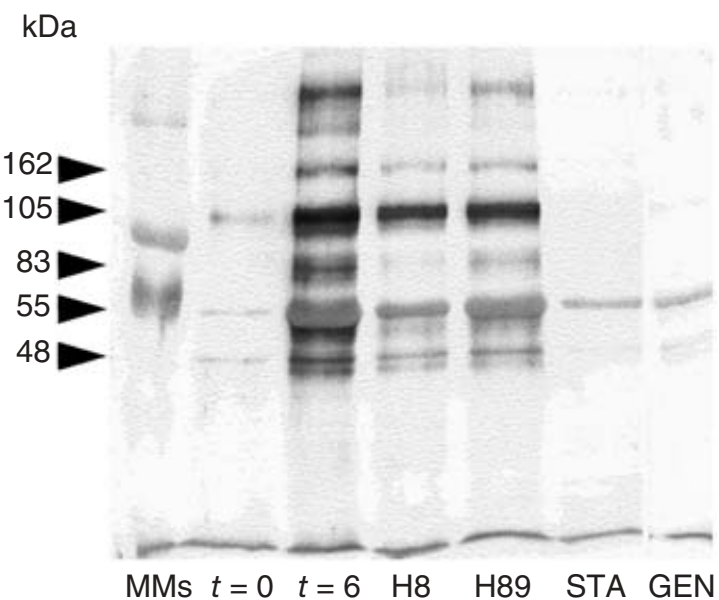

Fig. 6. Effect of protein tyrosine kinase and protein tyrosine kinase A inhibitors on tyrosine phosphorylation of soluble (Triton$\mathrm{X} 100)$ sperm proteins at baseline $(t=0)$ and after a $6 \mathrm{~h}$ incubation $(t=6)$ in Ham's $\mathrm{F} 10$ and human serum albumin at $37^{\circ} \mathrm{C}$ in $5 \% \mathrm{CO}_{2}$. Proteins were extracted from washed spermatozoa in SDS-buffer, solubilized with $0.05 \%$ Triton-X100, loaded on to a $7.5 \%(\mathrm{w} / \mathrm{v})$ polyacrylamide gel $\left(1 \times 10^{6} \mathrm{I}^{-1}\right.$ cells per lane), separated by electrophoresis, transferred to Immobilon $\mathrm{P}$ sheets and immunolabelled with phosphotyrosine antibody (4G10). Lanes were loaded with proteins extracted from untreated control spermatozoa ( $t=0$ and $t=6$ ) or spermatozoa incubated with the inhibitors for $6 \mathrm{~h}$ ( $\mathrm{H} 89, \mathrm{H} 8$, genistein (GEN), staurosporin (STA)). The lane with genistein was run on a different gel using the same sperm sample. Note that the order of the lanes is not the same as that of Fig. 5. Images were taken with a SPOT II digital camera. Molecular masses of bands were determined using a Kodak digital imaging system ( $v 2.1)(n=5)$. Arrowheads indicate the approximate molecular masses of the main visible protein bands. MMs: molecular markers.

pentoxifylline) and significantly reduced total tyrosine kinase activity in whole sperm extracts (Fig. 8). Soluble tyrosine kinase activity was reduced to a lesser extent. Most bands in western blots of whole-sperm extracts decreased in intensity (Fig. 10), and the incidence of tyrosine phosphorylated-inmmunoreactive spermatozoa was significantly reduced (Fig. 9). In the soluble fraction, the cAMP-dependent increase of the 55 and $48 \mathrm{kDa}$ bands was consistently reversed (Fig. 10), as were most of the enhanced motion parameters such as velocity, ALH and hyperactivation (Table 2, Fig. 7).

The inclusion of genistein resulted in inhibition of both tyrosine kinase and protein kinase $\mathrm{A}$ activity in the soluble fraction. Tyrosine kinase activity in the whole extract was less affected (Fig. 8). The incidence of tyrosine phosphorylated-immunoreactive spermatozoa as well as the intensity of phosphotyrosine-immunoreactive bands in western blots of whole-sperm extracts were decreased only partially (Figs 9, 10). Conversely, there was a very clear decrease in the 105, 81, 55 and $48 \mathrm{kDa}$ bands of the soluble fraction (Fig. 11). Occasionally, there was a further reduction in low molecular mass 


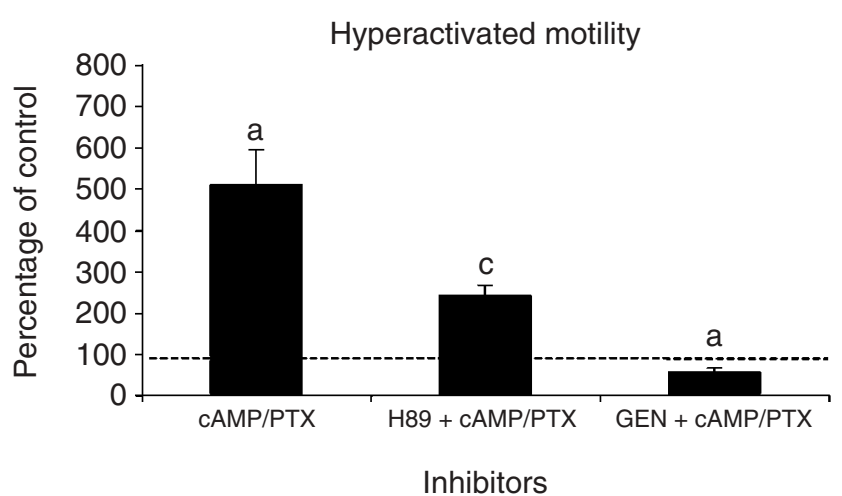

Fig. 7. Effect of protein tyrosine kinase (PTK) and protein kinase A (PKA) inhibitors on sperm hyperactivated motility stimulated by cAMP and pentoxifylline (PTX). Swim-up spermatozoa were incubated with or without PTK or PKA inhibitors (H89 and genistein (GEN)) for $30 \mathrm{~min}$ in Ham's F10 and human serum albumin at $37^{\circ} \mathrm{C}$ in $5 \% \mathrm{CO}_{2}$. Spermatozoa were stimulated further with $1 \mathrm{mmol}$ CAMP $\mathrm{I}^{-1}$ and $1 \mathrm{mmol}$ PTX $\mathrm{I}^{-1}$ for $1 \mathrm{~h}$ and motion parameters assessed using a Hamilton-Thorn motion analyser (v.10.8). Control spermatozoa were incubated with medium only. Data are expressed as percentages of the control $(90 \mathrm{~min}$ without inhibitors) indicated by a dashed line. However, the effect of the inhibitors should be evaluated in comparison with the spermatozoa treated with CAMP and PTK. Wilcoxon's signed-rank test was used to analyse CAMP and PTX data versus control. The rest of the data were compared against cAMP and PTX using Welch's test. Superscripts indicate significance of the data comparison (a: $P<0.0001$; c: $P<0.05)(n=10)$.

bands $(<40 \mathrm{kDa})$. Almost all motion parameters were significantly reduced, and a tenfold decrease in the percentage of hyperactivated spermatozoa was registered (Table 2, Fig. 7).

\section{Discussion}

Regulation of sperm motility is a complex phenomenon mediated by many factors, among which protein tyrosine phosphorylation plays an important role (Yunes et al., 1994; Leclerc et al., 1996; Luconi et al., 1996; Vijayaraghavan et al., 1997b; Tash and Bracho, 1998; Turner et al., 1999). In fact, phosphorylation and dephosphorylation of selected flagellar proteins in tyrosine residues have been shown to be linked to activated and hyperactivated sperm motility (Si and Okuno, 1999; Fujinoki et al., 2001).

Tyrosine phosphorylation in spermatozoa has been associated with capacitation, and it has become the focus of many studies as a critical signal transduction mechanism involved in regulation of sperm function (Visconti and Kopf, 1998). Studying mouse spermatozoa, Visconti et al. (1995b) demonstrated that capacitation and protein tyrosine phosphorylation were regulated by a CAMP-dependent pathway. The authors suggested that protein kinase A would be located upstream from

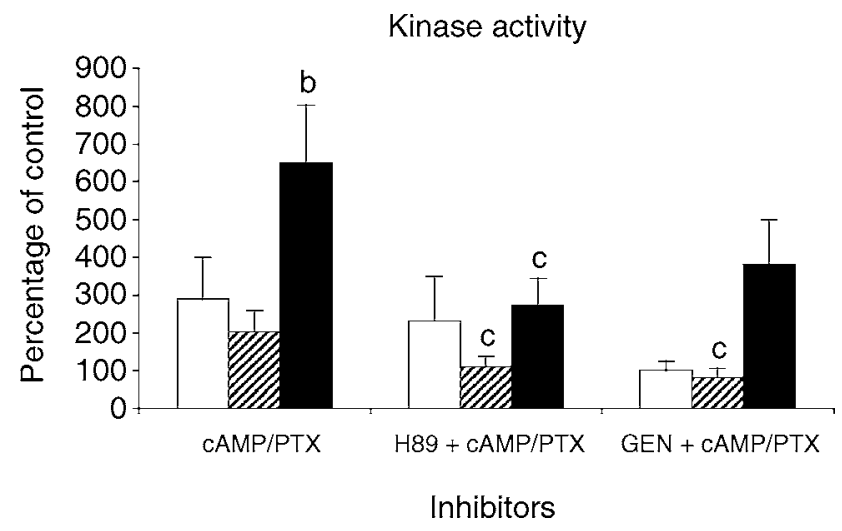

Fig. 8. Effect of kinase inhibitors on protein tyrosine kinase (PTK) and protein kinase $\mathrm{A}$ (PKA) activity of spermatozoa stimulated with $1 \mathrm{mmol}$ CAMP $\mathrm{I}^{-1}$ and $1 \mathrm{mmol}$ pentoxifylline (PTX) $\mathrm{I}^{-1}$ for $1 \mathrm{~h}$ in Ham's $\mathrm{F} 10$ and human serum albumin at $37^{\circ} \mathrm{C}$ in $5 \% \mathrm{CO}_{2}$. A colorimetric immunoreaction (ELISA) detecting tyrosine- and serine-phosphorylated target peptides was used to measure kinase activity. Data (mean $\pm \mathrm{SE}, n=10$ ) are expressed as percentage of control (spermatozoa incubated in Ham's F10 and human serum albumin without stimulators or inhibitors), indicated by a dashed line. However, the effect of the inhibitors (H89 and genistein (GEN)) should be evaluated in comparison with spermatozoa treated with CAMP and PTK. Wilcoxon's signed-ranked test was used to analyse CAMP and PTX data versus control. The rest of the data were compared against cAMP plus PTX using the Welch's test or paired $t$ test. Superscripts indicate significance of comparisons (c: $P<0.05$ ). $\square$ : solubilized PTK; $\mathbb{Z}$ : solubilized PKA; $\mathbf{\square}$ : PTK in whole sperm extracts.

tyrosine kinase; however, the possibility of a direct influence of capacitation-related changes on sperm protein tyrosine kinase and tyrosine phosphorylation remains. Such an inter-relationship between protein kinase $\mathrm{A}$ and tyrosine kinase pathways has also been demonstrated in spermatozoa of other species, including humans (Hayashi et al., 1987; Dey and Brokaw, 1991; Visconti et al., 1995b, 1999; Carrera et al., 1996; Osheroff et al., 1999; Si and Okuno, 1999). Concerning human spermatozoa, Osheroff et al. (1999) have demonstrated that cholesterol efflux, a phenomenon known to occur during capacitation, is associated with an increase in tyrosine phosphorylation in spermatozoa, apparently through an upregulation of protein kinase A. On the basis of data from the present study it is proposed that the activity of tyrosine kinase may be associated with motility regulation in a direct manner, effecting capacitationrelated changes in the movement of human spermatozoa without the necessary intervention of protein kinase A.

$\mathrm{H} 89$ is a specific protein kinase $\mathrm{A}$ inhibitor that operates by competing with ATP at the catalytic subunit of the kinase (Engh et al., 1996). There is ample evidence of its protein kinase A-inhibiting properties, both in somatic and sperm cells (Leclerc et al., 1996; Galantino-Homer et al., 1997; Harrison and Miller, 2000; Momura et al., 2000). Visconti et al. (1995b) 


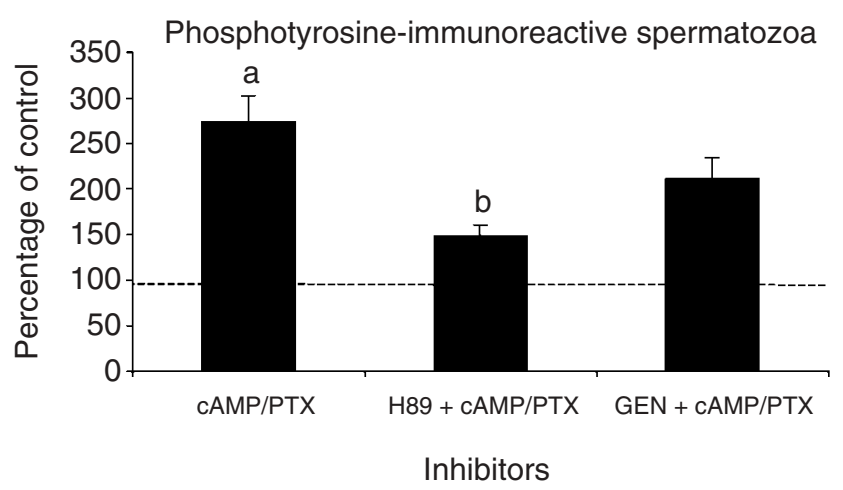

Fig. 9. Effect of protein kinase $A(P K A)$ and protein tyrosine kinase (PTK) inhibitors (H89 and genistein (GEN)) on the CAMP and pentoxifylline (PTX) enhanced-incidence of phosphotyrosineimmunoreactive sperm tails. Swim-up spermatozoa were incubated with the inhibitors for $30 \mathrm{~min}$ and then stimulated with $1 \mathrm{mmol}$ CAMP $~^{-1}$ and $1 \mathrm{mmol}^{\mathrm{PTX} \mathrm{I}} \mathrm{I}^{-1}$ for $1 \mathrm{~h}$ in Ham's F10 plus human serum albumin at $37^{\circ} \mathrm{C}$ in $5 \% \mathrm{CO}_{2}$. Spermatozoa were then fixed and permeabilized with methanol and labelled with phosphotyrosine monoclonal antibody (4G10) and fluorescein isothiocyanateconjugated anti-mouse IgG. Data (mean $\pm \mathrm{SE}, n=10$ ) are expressed as percentage of control (spermatozoa incubated in medium alone; dashed line). However, the effect of the inhibitors should be evaluated in comparison with spermatozoa treated with cAMP and PTK. Wilcoxon's signed-rank test was used to compare CAMP and PTX versus control data. Data with inhibitors were compared against cAMP and PTX data using Welch's test or paired $t$ test. Superscripts indicate the statistical significance of comparisons (a: $P<0.0001$; b: $P<0.001$; c: $P<0.05$ ).

showed that mouse spermatozoa treated with H89 displayed decreased tyrosine phosphorylation, acrosome reactivity and IVF potential. In the present study, in which human spermatozoa incubated under capacitating conditions were used, H89 significantly inhibited protein kinase $\mathrm{A}$; however, this inhibition did not translate into a reduction of tyrosine kinase activity. Consequently, phosphotyrosine-immunoreactive proteins were slightly decreased in western blots of both whole and soluble sperm protein extracts, and motion parameters suffered only a small reduction. However, addition of genistein, which inhibited tyrosine kinase but not protein kinase A, produced a significant reduction in phosphotyrosine proteins and motion parameters. Decreased tyrosine phosphorylation of flagellar proteins has been associated with diminished ability of spermatozoa to hyperactivate, probably due to decreased flexibility of the fibrous sheath of the sperm tail ( $\mathrm{Si}$ and Okuno, 1999). It is worth noting that in the present study, in addition to assessing the tyrosine phosphorylation of human sperm proteins using western blot analysis and their incidence using immunofluorescence, the sperm enzymatic activity specific to tyrosine and protein kinase A was measured, which has not been reported in the studies cited above.

H89 was reported by Leclerc et al. (1996) to inhibit capacitation in human spermatozoa, measured by the ability of spermatozoa to acrosome react,

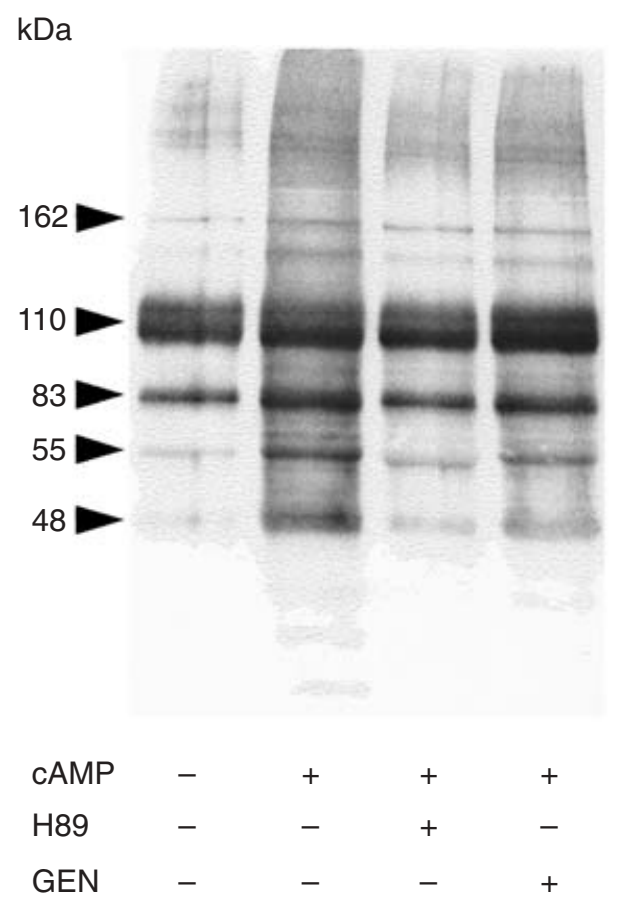

Fig. 10. Effect of protein kinase $A$ and protein tyrosine kinase inhibitors on sperm tyrosine phosphorylation at baseline and after stimulation with $1 \mathrm{mmol}$ CAMP $\mathrm{I}^{-1}$ and $1 \mathrm{mmol}$ pentoxifylline $\mathrm{I}^{-1}$ at $37^{\circ} \mathrm{C}$ in $5 \% \mathrm{CO}_{2}$ for $1 \mathrm{~h}$. Proteins were extracted from swim-up spermatozoa in SDS-buffer, loaded on to a $7.5 \%(\mathrm{w} / \mathrm{v})$ polyacrylamide gel $\left(1 \times 10^{6} \mathrm{I}^{-1}\right.$ cells per lane), separated by electrophoresis, transferred to immobilon $P$ sheets and immunolabelled with phosphotyrosine antibody (4G10). Lanes were loaded with proteins extracted from untreated spermatozoa and spermatozoa treated with CAMP and PTX alone or in combination with $\mathrm{H} 89$ and genistein (GEN). Images were taken with a SPOT II digital camera. Molecular masses of bands were determined using a Kodak digital imaging system ( $v 2.1)(n=4)$.

while decreasing tyrosine phosphorylation only slightly. Moreover, treatment with $\mathrm{H} 89$ induced a small decrease in sperm motion parameters. Inclusion of Rp-cAMPS, an inactive analogue of cAMP which competes with cAMP for the RII subunit of protein kinase A, partially inhibited capacitation and tyrosine phosphorylation and showed no effect on motility. These findings are in agreement with those reported in the present study.

As mentioned above, the involvement of protein kinase $\mathrm{A}$ in the regulation of sperm tyrosine phosphorylation of sperm proteins has been well documented. However, results of the present study indicate that activation of protein kinase $\mathrm{A}$ is not a sine qua non condition for capacitation-related upregulation of sperm tyrosine kinase activity, at least for the activity involved in the modulation of human sperm motility. Supporting this contention, Vijayaraghavan et al. (1997c) reported that inhibition of protein kinase A catalytic subunit in bovine spermatozoa had little effect on basal or chlorodeoxyadenosine-stimulated sperm motility. 


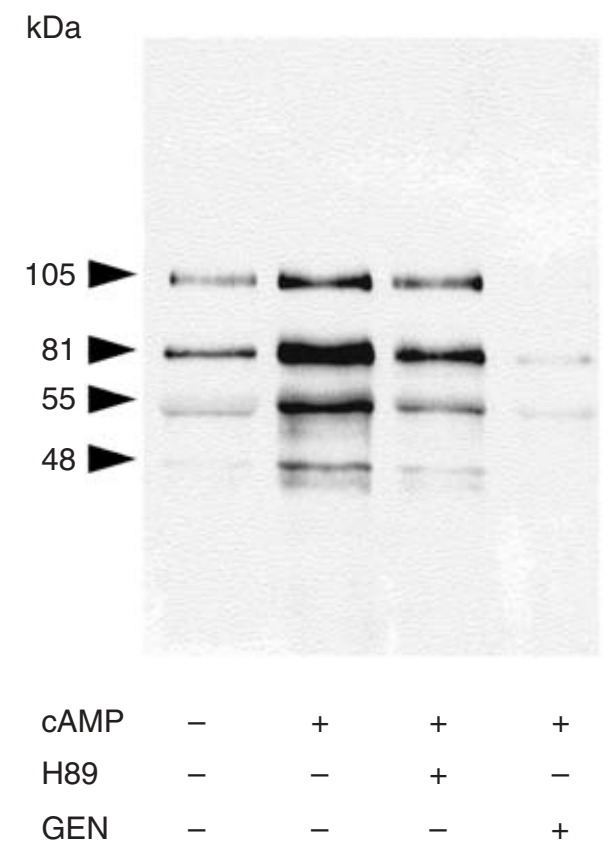

Fig. 11. Effect of protein kinase $A$ and protein tyrosine kinase inhibitors on tyrosine phosphorylation of soluble (Triton-X100) sperm proteins stimulated by $1 \mathrm{mmol} \mathrm{CAMP} \mathrm{I}^{-1}$ and $1 \mathrm{mmol}$ pentoxifylline (PTX) $\mathrm{I}^{-1}$ at $37^{\circ} \mathrm{C}$ in $5 \% \mathrm{CO}_{2}$ during $1 \mathrm{~h}$ of incubation. Proteins were extracted from swim-up spermatozoa in SDS-buffer, solubilized with $0.05 \%$ Triton-X100, loaded on to a $7.5 \%(\mathrm{w} / \mathrm{v})$ polyacryamide gel $\left(1 \times 10^{6} \mathrm{I}^{-1}\right.$ cells per lane), separated by electrophoresis, transferred on to Immobilon P sheets and immunolabelled with phosphotyrosine antibody (4G10). Lanes were loaded with proteins extracted from untreated spermatozoa and spermatozoa treated with CAMP and PTX alone or in combination with $\mathrm{H} 89$ and genistein (GEN). Images were taken with a SPOT II digital camera. Molecular masses of bands were determined using a Kodak digital imaging system ( $v 2.1)(n=4)$. Arrowheads indicate the approximate molecular mass of the main visible protein bands.

Other factors, besides activation of the protein kinase A pathway, may modulate tyrosine kinase activity in the sperm tail. The redox status of the sperm cells has a profound effect in tyrosine phosphorylation (Aitken et al., 1995; Krzyzosiak et al., 2000). Sperm tyrosine kinase activity has also been shown to be influenced by $\mathrm{Ca}^{2+}$ as well as other cations (Berruti, 1994; Aitken et al., 1995; Luconi et al., 1996). $\mathrm{Ca}^{2+}$ can activate phosphatases, which may indirectly affect tyrosine phosphorylation (Tash and Bracho, 1994; Leclerc et al., 1996; Luconi et al., 1996; Smith et al., 1996). Travis et al. (2001) demonstrated that ATP specifically produced by a glycolytic pathway in the principal piece of the flagellum, acting downstream from cAMP, was strictly required, and represented an important regulator for protein tyrosine phosphorylation events at the sperm tail.

In the present study, contrary to H89, a less specific protein kinase A inhibitor, $\mathrm{H} 8$, which competes with ATP at the catalytic subunit, inhibited both sperm protein kinase $\mathrm{A}$ and tyrosine kinase activity, reducing tyrosine phosphorylation. A more marked reduction was observed when staurosporin, a wide-spectrum kinase inhibitor, was used. Protein kinase A inhibition caused by H89, $\mathrm{H} 8$ or staurosporin was similar in magnitude $(58,59$ and $52 \%$ of control, respectively). However, the magnitude of the decrease in tyrosine phosphorylation induced by these compounds was different, and directly related to their extent of inhibition of tyrosine kinase activity. Most studies citing an upstream regulation of tyrosine phosphorylation by protein kinase $\mathrm{A}$ have not measured specific kinase activity and the impact of the used inhibitors on this parameter. Results of the present study show no correlation between protein kinase A inhibition and downregulation of human sperm tyrosine phosphorylation. Interestingly, inhibition of both tyrosine and serine-theronine kinase activities at the same time had a differential impact on motion parameters, with a net increase in hyperactivated spermatozoa. Similar changes have been reported as a result of increased $\mathrm{PP}_{2} \mathrm{~B}$ phosphatase activity (Tash et al., 1988; Tash and Bracho, 1994).

The involvement of a protein kinase $\mathrm{A}$ and tyrosine kinase cross-talk in the regulation of human sperm motility parameters was explored further by incubating spermatozoa with a permeable analogue of CAMP, dibutyryl CAMP, and a phosphodiesterase inhibitor, pentoxifylline, to prevent CAMP intracellular degradation. The stimulation of the protein kinase A transduction pathway resulted in a selective increase in the magnitude of certain sperm motion parameters such as velocity (VAP and VCL) and ALH as well as a slight reduction in linearity. Higher curvilinear velocity with lower linearity and greater amplitude of head displacement defines hyperactivated motility in human spermatozoa (Mortimer et al., 1984; Burkman, 1991). The percentage of hyperactivated spermatozoa in the aliquots incubated with CAMP plus pentoxifylline was five times more than in the control (no protein kinase A stimulation). Such enhancement has been reported by Tesarik et al. (1992), Pang et al. (1993), Lewis et al. (1994) and Nassar et al. (1999). In parallel with those modifications in the motion characteristics of spermatozoa, an increase in the protein kinase A activity of the soluble fraction as well as in the tyrosine kinase activity of both soluble and whole-cell extracts was recorded in the present study. Phosphotyrosine-containing proteins were increased in both fractions.

Inhibition of the catalytic activity of protein kinase A by addition of $\mathrm{H} 89$ blunted the enhacement of sperm motility and tyrosine phosphorylation, highlighting participation of kinase $A$ in the modulation of these phenomena. However, the reduction in CAMP and pentoxifylline-stimulated motion parameters was much more marked when genistein was included in the medium. The changes in sperm motion correlated with a significant reduction in tyrosine kinase activity and the 
tyrosine-phosphorylated proteins of the soluble sperm fraction.

Both soluble and insoluble phosphotyrosinecontaining proteins have been associated with sperm motility. Notably, the tyrosine phosphorylation status of a $55 \mathrm{kDa}$ protein isolated from the soluble supernatant of bovine spermatozoa has been shown to be associated with the presence and stimulation of motility (Vijayaraghavan et al., 1997b). The degree of tyrosine phosphorylation of this protein was much higher in motile caudal than in immotile caput epididymal spermatozoa. Motility activators, isobutylmethyl xanthine and 8-bromo-cAMP, increased the phosphotyrosine content of the $55 \mathrm{kDa}$ protein. This protein was later identified as a form of glycogen synthase kinase, GSK-3 (Vijayaraghavan et al., 2000). In the present study, a $55 \mathrm{kDa}$ protein band identified in the soluble fraction of human spermatozoa clearly correlated with motility changes imposed by the capacitation process, cAMP and kinase inhibitors.

Soluble cytosolic proteins may connect capacitationassociated changes to structural proteins involved in sperm movement. A $37 \mathrm{kDa}$ protein soluble in TritonX100, antigenically related to calpactin II, has been identified in human sperm extracts (Berruti, 1988). Calpactins comprise a family of $\mathrm{Ca}^{2+}$-binding proteins that in somatic cells mediate plasma membranecytoskeleton interactions. Another group of proteins with $\mathrm{Ca}^{2+}$-binding properties has recently been characterized in human spermatozoa (Naaby-Hansen et al., 2002). The main $\mathrm{Ca}^{2+}$-binding isoform is an acidic, $86 \mathrm{kDa}$ protein, known as CABYR, the ability of which to bind $\mathrm{Ca}^{2+}$ is associated with its tyrosine-phosphorylated status. Both properties of this protein increase during capacitation. Interestingly, CABYR has been localized to the principal piece of human spermatozoa, over the fibrous sheath area, with a very similar distribution to that of A kinase anchoring proteins (AKAPs) 4 and 3 (Johnson et al., 1997; Mandal et al., 1999). Changes in the sperm plasma membrane that occur during capacitation might be linked to tail cytoskeletal components, such as the fibrous sheath, through $\mathrm{Ca}^{2+}$-binding proteins such as calpactins or CABYR.

In the present study, the tyrosine phosphorylation of proteins with a molecular mass similar to that of AKAP4 and CABYR (81-86 kDa) was significantly affected by both tyrosine and A kinase inhibition. AKAPs have been identified in spermatozoa of different species (Carrera et al., 1994, 1996; Moss et al., 1999; Vijayaraghavan et al., 1999). They are present in the insoluble fraction of sperm extracts and some of them have been identified as the major tyrosine-phosphorylated proteins of the fibrous sheath, a cytoskeletal structure that extends all along the principal piece of the spermatozoon and is involved in modulating flagellar bending ( $\mathrm{Si}$ and Okuno, 1993). More interesting is the role of AKAPs as scaffolding proteins that bring into close interaction several signal transduction molecules such as kinases, phosphatases, $\mathrm{Ca}^{2+}$-binding proteins, $\mathrm{Ca}^{2+}$ channels and membrane receptors (for a review, see Dodge and Scott, 2000). Anchoring proteins located in the sperm tail might act as multimeric transductional complexes integrating signals coming from plasma membrane and cytosol, and efficiently transferring them to axonemal and paraaxonemal proteins that are the ultimate regulators of sperm movement.

In conclusion, tyrosine phosphorylation in human spermatozoa appears to be directly influenced by capacitation-related changes that occur during incubation in protein-supplemented complete medium in vitro. The same or similar changes also stimulate cAMPdependent kinase activation, which besides phosphorylating proteins in serine and theronine residues facilitates tyrosine phosphorylation. This stimulatory pathway appears to activate certain sperm motility parameters preferentially, such as velocity and amplitude of lateral head displacement, increasing the proportion of spermatozoa that display hyperactivated motility. These changes occur in parallel to an increase in soluble tyrosine kinase activity and its resulting soluble phosphoproteins. Insoluble tyrosine kinase activity is also augmented when the protein kinase A pathway is stimulated, increasing tyrosine phosphorylation of structural proteins such as AKAPs and axonemal proteins. Both systems are closely interrelated at the sperm tail and are critically involved in regulation of human sperm motility.

This study was supported by an intramural grant of the CONRAD Program (USAID). The views of the authors do not necessarily reflect those of the CONRAD Program or USAID. The authors wish to thank L. Holas for her help in the preparation of this manuscript, C. Farrigan for the excellent editorial assistance and the USAIDIndia mission for supporting the fellowship of M. Bajpai.

\section{References}

Aitken RJ, Peterson M, Fisher H, Buckingham DW and van Duin M (1995) Redox regulation of tyrosine phosphorylation in human spermatozoa and its role in the control of human sperm function Journal of Cell Science 108 2017-2025

Berruti G (1988) Calpactin-like proteins in human spermatozoa Experimental Cell Research 179 374-384

Berruti G (1994) Biochemical characterization of the boar sperm 42 kilodalton protein tyrosine kinase: its potential for tyrosine as well as serine phosphorylation towards microtubule-associated protein 2 and histone H 2B Molecular Reproduction and Development 38 386-392

Burkman LJ (1991) Discrimination between non-hyperactivated and classical hyperactivated motility patterns in human spermatozoa using computerized analysis Fertility and Sterility 2 363-371

Carrera A, Gerton GL and Moss SB (1994) The major fibrous sheath polypeptide of mouse sperm: structural and functional similarities to the A-kinase anchoring proteins Developmental Biology $1272-284$

Carrera A, Moos J, Ning XP, Gerton GL, Tesarik J, Kopf GS and Moss SB (1996) Regulation of protein tyrosine phosphorylation in human sperm by a calcium/calmodulin-dependant mechanism: identification of $A$ kinase anchor proteins as a major substrates for tyrosine phosphorylation Developmental Biology 180 284-296 
Dey CS and Brokaw CJ (1991) Activation of Ciona sperm motility: phophorylation of dynein polypeptides and effects of a tyrosine kinase inhibitor Journal of Cell Science 100 815-824

Dodge K and Scott JD (2000) AKAP79 and the evolution of the AKAP model FEBS Letters 476 58-61

Engh RA, Girod A, Kinzel V, Huber R and Bossemeyer D (1996) Crystal structures of catalytic subunit of CAMP-dependant protein kinase in complex with isoquinolinesulfonyl protein kinase inhibitors $\mathrm{H7}, \mathrm{H} 8$ and H89 Journal of Biological Chemistry 4226 157-26164

Fujinoki M, Ohtake H and Okuno M (2001) Tyrosine phosphorylation and dephosphorylation associated with motility and hamster spermatozoa Biomedical Research 22 147-155

Galantino-Homer HL, Visconti PE and Kopf GS (1997) Regulation of protein tyrosine during bovine sperm capacitation by a cyclic adenosine $3^{\prime}, 5^{\prime}$ monophosphate-dependent pathway Biology of Reproduction 3707 709

Harrison RA and Miller NG (2000) cAMP-dependant protein kinase control of plasma lipid architecture in boar sperm Molecular Reproduction and Development 2 220-228

Hayashi H, Yamamoto K, Yonekawa H and Morisawa M (1987) Involvement of tyrosine protein kinase in the initiation of flagelar movement in rainbow trout spermatozoa Journal of Biological Chemistry 26216692 16698

Jeyendran RS, Van der Ven $\mathbf{H H}$, Perez-Palaez $M$, Crabo BG and Zaneveld LJ (1984) Development of an assay to assess the functional integrity of human sperm membrane and its relationship to other semen characteristics Journal of Reproduction and Fertility 70219 228

Johnson L, Foster JA, Haig-Ladewig L, Vanscoy H, Moss SM and Gerton GL (1997) Assembly of AKAP82, a protein kinase A anchor protein, into the fibrous sheath of mouse sperm Developmental Biology 192340 350

Krzyzosiak J, McMillan G, Molan P and Vishwanath R (2000) Protein tyrosine phosphorylation during prolonged in vitro incubation of ejaculated bovine spermatozoa is regulated by the oxidative state of the medium Biology of Reproduction 62 1615-1623

Leclerc P, deLamirande E and Gagnon C (1996) Cyclic adenosine 3',5' monophosphate-dependant regulation of protein tyrosine phosphorylation in relation to human sperm capacitation and motility Biology of Reproduction 55 684-692

Levitz SM and Diamond RD (1985) A rapid colorimetric assay of fungal viability with tetrazolium salt MTT Journal of Infectious Diseases $\mathbf{1 5 2}$ 938-945

Lewis SE, McKinney KA and Thompson W (1994) Influence of pentoxifylline on human sperm motility in asthenozoospermic individuals using computer-assisted analysis Archives of Andrology 3 175-183

Luconi M, Krausz C, Forti G and Baldi E (1996) Extracelluar calcium negatively modulates tyrosine phosphorylation and tyrosine kinase activity during capacitation of human spermatozoa Biology of Reproduction $\mathbf{5 5}$ 207-215

Mandal A, Naaby-Hansen S and Wolkowicz MJ et al. (1999) A testis-specific 95 kilodalton fibrous sheath antigen that undergoes tyrosine phosphorylation in capacitated human spermatozoa Biology of Reproduction 61 1184-1197

Momura M, Inaba K and Morisawa M (2000) Cyclic AMP- and calmodulindependent activation in phosphorylation of 21 and $26 \mathrm{kDa}$ proteins in axoneme is a prerequisite for SAFF-induced motile ascidian spermatozoa Development, Growth and Differentiation 2 129-138

Mortimer D, Courtot AM, Giovangrandi Y, Jeulin C and David G (1984) Human sperm motility after migration into, and incubation in, synthetic media Gamete Research 9 131-144

Moss SB, Turner RMO, Berkert KL, VanScoy-Butt $\mathbf{H}$ and Gerton GL (1999) Conversation and function of a bovine sperm A-kinase anchor protein homologous to mouse AKAP82 Biology of Reproduction 61335 342

Naaby-Hansen S, Mandal A, Wolkowicz MJ et al. (2002) CABYR, a novel calcium-binding tyrosine phosphorylation-regulated fibrous sheath protein involved in capacitation Developmental Biology 242 236-254
Nassar A, Mahony M, Morshedi M, Lin MH, Srisombut C and Oehninger S (1999) Modulation of sperm tail protein tyrosine phosphorylation by pentoxifylline and its correlation with hyperactivated motility Fertility and Sterility 5 919-923

Osheroff JE, Visconti PE, Valenzuela JP, Travis AJ, Alvarez J and Kopf GS (1999) Regulation of human sperm capacitation by a cholesterol effluxstimulated signal transductional pathway leading to protein kinase Amediated upregulation of protein tyrosine phosphorylation Molecular Human Reproduction 11 1017-1026

Pang SC, Chan PJ and Lu A (1993) Effects of pentoxifylline on sperm motility and hyperactivation in normozoospermic and normokinetic semen Fertility and Sterility 2 336-343

Si Y and Okuno $\mathbf{M}$ (1993) The sliding of the fibrous sheath through the axoneme proximally together with microtuble extrusion Experimental Cell Research 1 170-174

Si Y and Okuno M (1999) Role of tyrosine phosphorylation of flagellar proteins in hamster sperm hyperactivation Biology of Reproduction $\mathbf{6 1}$ $240-246$

Smith GD, Wolf DP, Trautman KC, da Cruz e Silva EF, Greengard P and Vijayaraghavan S (1996) Primate sperm containing protein phosphatase 1, a biochemical mediator of motility Biology of Reproduction 54719 727

Tash JS and Bracho GE (1994) Regulation of sperm motility: emerging evidence for a major role for protein phosphatases Journal of Andrology 6 505-509

Tash JS and Bracho GE (1998) Identification of phosphoproteins coupled to initiation of motility in live epididymal mouse sperm Biochemical and Biophysical Research Communications 251 557-563

Tash JS, Krinks M, Patel J, Means RL, Klee CB and Means AR (1988) Identification, characterization and functional correlation of calmodulin-dependant protein phosphatase in sperm Journal of Cell Biology 106 1625-1633

Tesarik J, Thebault A and Testart J (1992) Effect of pentoxifylline on sperm movement characteristics in normozoospermic and asthenozoospermic specimens Human Reproduction 9 1257-1263

Travis AJ, Jorgez CJ, Merdiushev T, Jones BH, Dess DM, Diaz-Cueto L, Storey BT, Kopf GS and Moss SB (2001) Functional relationships between capacitation-dependent cell signaling and compartmentalized metabolic pathways in murine spermatozoa Journal of Biological Chemistry 276 7630-7636

Turner RMO, Erikson RLM, Gerton GL and Moss SB (1999) Relationship between sperm motility and the processing and tyrosine phosphorylation of two human sperm fibrous sheath pro-proteins, hAKAP82 and hAKAP82 Molecular Human Reproduction 9816 824

Vijayaraghavan S, Goueli SA, Davey MP and Carr DW (1997a) Protein kinase A-anchoring inhibitor peptides arrest mammalian sperm motility Journal of Biological Chemistry 8 4747-4752

Vijayaraghavan S, Trautman KD, Goueli SA and Carr DW (1997b) A tyrosine-phosphorylated 55- kilodalton motility-associated bovine sperm protein is regulated by cyclic adenosine $3^{\prime}, 5^{\prime}$-monophosphates and calcium Biology of Reproduction 56 1450-1457

Vijayaraghavan S, Olson GE, NagDas S, Winfrey VP and Carr DW (1997C) Subcellular localization of the regulatory subunits of cyclic adenosine $3^{\prime}, 5^{\prime}$-monophosphate-dependent protein kinase in bovine spermatozoa Biology of Reproduction 57 1517-1523

Vijayaraghavan S, Liberty GA, Mohan J, Winfrey VP, Olson GE and Carr DW (1999) Isolation and molecular characterization of AKAP110, a novel, sperm-specific kinase A-anchoring protein Molecular Endocrinology 13 705-717

Vijayaraghavan S, Mohan J, Gray H, Khatra B and Carr DW (2000) A role for phosphorylation of glycogen synthase kinase- $3 \alpha$ in bovine sperm motility regulation Biology of Reproduction 62 647-654

Visconti PE and Kopf GS (1998) Regulation of protein phosphorylation during sperm capacitation Biology of Reproduction 59 1-6

Visconti PE, Bailey JL, Moore GD, Pan D, Olds-Clarke P and Kopf GS (1995a) Capacitation of mouse spermatozoa. I. Correlation between the capacitation state and protein tyrosine phosphorylation Development 21 1129-1137 
Visconti PE, Moore GD, Bailey JL, Leclerc P, Connors SA, Pan D, OldClarke P and Kopf GS (1995b) Capacitation of mouse spermatozoa. II. Protein tyrosine phosphorylation and capacitation are regulated by a cAMP-dependant pathway Development 121 1139-1150

Visconti PE, Savage-Stewart J, Blasco A, Battaglia L, Miranda P and Kopf GS (1999) Roles of bicarbonate, cAMP, and protein tyrosine phosphorylation on capacitation and the spontaneous acrosome reaction of hamster sperm Biology of Reproduction 61 76-84

World Health Organization (1999) Computer-aided sperm analysis. In: WHO Laboratory Manual for the Examination of Human Semen and Sperm-Cervical Mucus Interaction pp 90-93 4th Edn. Cambridge University Press, Cambridge
Yanagimachi R (1994) Mammalian fertilization. In The Physiology of Reproduction pp 189-317 Eds E Knobil and JD Neill. 2nd Edn. Raven Press, New York

Yunes R, Doncel GF and Acosta AA (1994) Phosphotyrosine-containing proteins and hyperactivated motility in human sperm Fertility and Sterility ASRM Annual Meeting Supplement S3

Received 23 December 2002.

First decision 11 February 2003.

Revised manuscript received 12 March 2003.

Accepted 21 March 2003. 